\title{
Anti-hemolytic, Anti-lipid Peroxidation and Antioxidant Properties of Three Plants Locally Used to Treat Metabolic Disorders: Allium sativum, Persea americana and Citrus sinensis
}

\author{
Boris G. K. Azantsa ${ }^{1}$, Mary-Ann A. Mbong ${ }^{1}$, Guy RN Takuissu ${ }^{1}$, Rosane S. Matsinkou ${ }^{1}$, Imelda L. N. Djuikoo ${ }^{1}$, \\ Janvier F. Youovop ${ }^{1}$, Judith L. Ngondi ${ }^{1} \&$ Julius E. Oben $^{1}$ \\ ${ }^{1}$ Laboratory of Nutrition and Nutritional Biochemistry, Department of Biochemistry, University Of Yaounde 1, \\ p.o. Box: 812 Yaounde, Cameroon \\ Correspondence: Dr. Azantsa K. G. Boris, Laboratory of Nutrition and Nutritional Biochemistry, Department of \\ Biochemistry, University Of Yaounde 1, PO. Box: 812 Yaounde, Cameroon. Tel: +237-677-920-184. E-mail: \\ borisazantsa@yahoo.fr
}

Received: March 31, 2019

Accepted: April 19, 2019 Online Published: June 25, 2019

doi:10.5539/jfr.v8n4p89

URL: https://doi.org/10.5539/jfr.v8n4p89

\begin{abstract}
Citrus sinensis, Persea americana and Allium sativum are good sources of large number of various bioactive substances including antioxidants. Antioxidants play an essential role in the prevention and treatment of type 2 diabetes and other metabolic diseases. This study was conducted to evaluate and compare the anti- lipid peroxidation, anti-hemolytic and antioxidant capacity of aqueous extracts of the three plants in vitro. Polyphenolic and flavonoids content of aqueous extracts (EA) of plants were determined. The anti-lipid peroxidation was evaluated on homogenates of rat liver. Anti-haemolytic effects were assessed using erythrocyte system model induced free radicals from human red blood cells. Total antioxidant capacity and antiradical or scavenging capacity were evaluated on biological free radical systems $(\mathrm{OH}, \mathrm{NO})$ and synthetic radicals (DPPH and $\mathrm{ABTS}^{+}$). Results showed that, different extracts possess variable amounts of polyphenolic compounds. They exhibited significant anti-hemolytic and anti-lipid peroxidation activities. Aqueous extracts of Citrus sinensis are powerful scavenger of $\mathrm{OH}^{\cdot}\left(\mathrm{IC}_{50}=1.05 \times 10^{-3} \mathrm{mg} / \mathrm{ml}^{\prime}\right.$ and $\mathrm{NO}\left(\mathrm{IC}_{50}=1.29 \times 10^{-3} \mathrm{mg} / \mathrm{ml}\right)$ free radicals while Persea americana seed extract possesses the highest anti-lipid peroxidation capacity $(59.72 \%)$ and the best scavenging capacity against DPPH and ABTS. Red blood cells were highly protected (at $97.87 \%$, p $<0.05$ ) by Allium sativum extract at $1 \mathrm{mg} / \mathrm{mL}$ and Citrus sinensis $(87.7 \%, \mathrm{p}<0.05)$. Therefore, anti-hemolytic, anti-lipid peroxidation effects of the aqueous extracts of the three plants can justify their use and efficacy in alternative treatment of metabolic diseases.
\end{abstract}

Keywords: anti-hemolytic, anti-lipid peroxidation, antioxidant, plant extracts, diabetes mellitus

\section{Introduction}

Type II diabetes mellitus (T2DM) is a metabolic disorder characterized by prolonged hyperglycemia, insulin resistance and/or reduced insulin sensitivity (Kooti, Maryam, Zahra, Damoon \& Majid, 2016). It is associated to several complications including macro and micro-angiopathies. T2DM constitutes a risk factor for cardiovascular diseases. A recent report estimates at 500 million its worldwide prevalence; comparable in high and low-income countries (Kaiser, Nicole \& Wouter, 2018). Its diagnosis includes measurement of fasting blood glucose and glycated haemoglobin (HbA1c) (Aggarwal et al., 2013). In T2DM patients, hemorheological parameters are often disturbed due to excess glucose concentration in the blood. This affects haematocrit, plasma proteins, erythrocyte aggregation and deformability (Youn et al., 2017). All these disturbances affect blood viscosity of diabetic patients compared to healthy patients (Young, Michael, Mooney \& Daniel, 2008). Erythrocytes or red blood cells (RBC) play a key role in the metabolism as well as in oxygen $\left(\mathrm{O}_{2}\right)$ and drug transportation. Attacks of polyunsaturated fatty acid of lipids and proteins found in erythrocyte membrane are responsible for hemolysis and can justify the greater osmotic fragility observed in diabetic patients. The osmotic fragility has been proven to be positively correlated to glycated hemoglobin (Kung, Tseng \& Wang, 2009; Ebrahimzadeh, Nabavi \& Nabavi, 2009; Afsar et al., 2016). Hyperglycaemia in T2DM causes changes in the shape of RBC and provokes a mild corrosion, making them to aggregate, leading to enhanced viscosity and retarded motility (Alshalhi et al., 2018; Leal, Merel \& Giel, 2018). Cell membranes of RBC are made up of 
proteins and lipids, mainly phospholipids. Phospholipids ensure its biological function, but glycation of membrane proteins alters its function. Such alterations occur when the generation of ROS resulting from hyperglycaemia creates an oxidative stress (Rodrigo, Bächle, Araya, Prat \& Passalacqua, 2007, Omale \& Alewo, 2014). Lipid peroxidation also disturbs activities of membrane bound enzymes by changing phospholipids and fatty acid compositions, decreasing $\mathrm{Na}+/ \mathrm{K}^{+}$-ATPase activity (Rodrigo et al., 2007; Viskupicova et al., 2015). In vitro, an increased concentration of glucose causes hemolysis, eryptosis, and calcium accumulation. It intensifies lipid peroxidation and loss of activities of erythrocyte enzymes like glutathione-s-transferase and reductase (Viskupicova et al., 2015; Asmat, Khan \& Ismail, 2016).

There are various side effects associated to different classes of prescribed drugs; varying from nausea, diarrhea, vomiting and hypoglycemia. Medicinal plants offer less side effects, are more affordable and effective (Kooti et al., 2016). Allium sativium bulb, Persea americana seed and stem bark of Citrus sinenis have been intensively used to treat diabetes (Bordoloi, \& Dutta, 2014). Their effects on the reduction of glycaemia solely or combined have been reported (Azantsa et al., 2017; Azantsa et al., 2018), with proven safety and efficacy (Yasir, Das, \& Kharya, 2010). Persea americana mill (Lauraceae) is a tree plant also called avocado or alligator pear (Ranade \& Thiagarajan, 2015). It is recommended for anaemia, exhaustion, hyper-cholesterolemia, hypertension, gastritis, and gastro-duodenal ulcer (Antia, Okokon \& Okon, 2005; Kumala, Utami, \& Sari, 2013). The methanolic extracts obtained from the seeds demonstrated high in vitro DPPH scavenging activity (Vinha, Moreira, \& Barreira, 2013; Dreher \& Davenport, 2013).

Allium sativum also called garlic, is a member of the Liliaceae family. It is a cultivated food and spice highly exploited throughout the world. Allium sativum consumption has significant effects on lowering blood pressure, prevention of atherosclerosis, reduction of serum cholesterol and triglyceride, blood glucose and inhibition of platelet aggregation (Eidi et al., 2006; Chan et al., 2013). Allium sativum scavenges ROS by increasing the cellular antioxidant enzymes superoxide dismutase, catalase, glutathione peroxidase, and enhancing glutathione levels (Borek, 2001; Bayan, Koulivand \& Gorji, 2014). Ethanolic extracts of Allium sativum L. bulbs possess antioxidant potential against hydroxyl peroxide and reducing power ability on DPPH radicals (Narendhirakannan \& Rajeswari, 2010; Huzaifa, Labaran, Bello, \& Olatunde, 2014).

Citrus sinensis $L$. that belongs to the Rutaceae family is one of the most cultivated plants in the world. It is a source of food and vitamins for humans (Jensen et al., 2008; Etebu, \& Nwauzoma, 2014). The leaves' extracts of Citrus sinensis possess antioxidant activities (Azantsa et al., 2017a). If the antioxidant properties of some extracts of these plants have been reported, no comparative studies exist on the efficacy of their aqueous extracts. This study aims at comparing the anti-hemolytic effect of the three plants based on radical-induced erythrocyte lyses; to assess the anti-lipid peroxidation effects; to determine the antioxidant and scavenging capacity against free radicals in vitro.

\section{Method}

\subsection{Chemicals and Reagents}

Folin-ciocalteu reagent, catechin, ethanol, aluminium chloride $\left(\mathrm{AlCl}_{3}\right)$, potassium acetate $\left(\mathrm{CH}_{3} \mathrm{COOK}\right)$, quercetin, hydrogen chloride $(\mathrm{HCl})$, sodium chloride $(\mathrm{NaCl})$, ferric sulfate $\left(\mathrm{FeSO}_{4}\right)$, thiobarbituric acid (TBA), ascorbic acid, sulfanilic acid, sodium nitroprusside, sulphuric acid, naphtylethylene diamine dichloride and copper sulfate $\left(\mathrm{CuSO}_{4}\right)$ were purchased from Sigma (USA). Human blood sample was purchased from CHU-hospital, Yaounde, Cameroon.

\subsection{Collection of Plants and Preparation of Aqueous Extracts}

Persea americana seeds and stem bark of Citrus sinensis were harvested in march 2017 in Mendong -Yaounde (City capital of Cameroon). Allium sativum cloves were bought from Mokolo market, Yaounde, Cameroon. Citrus sinensis $\mathrm{L}$ (voucher $\mathrm{N}^{\circ}$ 25859/SRF), P.americana mill (voucher $\mathrm{N}^{\circ} 31940 \mathrm{HNC}$ ), Allium sativum (voucher $\mathrm{N}^{\circ} 44810 \mathrm{HNC}$ ) were identified at the National Herbarium.

The collected plant parts were rinsed with distilled water. The peels of Allium sativum bulb and Persea americana seeds were removed from the flesh. Parts were cut into small pieces and shade dried in open air till constant weight. Dried materials were ground to obtain powder. One hundreds (100) g of each powder was mixed with $800 \mathrm{ml}$ distilled water. The mixture was vigorously shaken and kept for 24 hours, to enhance proper dissolution and extraction of the bioactive compounds in the samples. Each solution was shaken vigorously and filtered with Whatmann filter paper (Whatmann Int. Ltd., Maidstone, U.K) at room temperature. Filtrates obtained were evaporated in a rotary evaporator (BUCHI Rotavapor R-114, Switzerland) at $45^{\circ} \mathrm{C}$ until the extracts became dry. The aqueous extracts obtained were stored in polyethylene bags to avoid moisture. 


\subsection{Determination of Total Polyphenol Content}

The total phenolic content of each extract was determined spectrophotometrically, using the Folin-Ciocalteu method as described by Singleton and Rossi (1965). Briefly, to $30 \mu \mathrm{L}$ of the extract, $1 \mathrm{~mL}$ of the Folin- ciocalteu reagent (diluted 10 times with distilled water) was added. Thirty minutes after incubation at $25{ }^{\circ} \mathrm{C}$, absorbance was read at $750 \mathrm{~nm}$ with a spectrophotometer. Catechin was used as the standard at different concentrations $(0-$ $1000 \mu \mathrm{g} / \mathrm{mL}$ ) for the calibration curve. Analyses were performed in triplicate and the content of phenolic compounds in extracts was expressed in $\mu \mathrm{g}$ equivalent catechin/mg of extract.

\subsection{Determination of Flavonoids Content}

Total flavonoids content was evaluated using the method described by Aiyegoro and Okoh (2010). To $1 \mathrm{~mL}$ of extract $(1 \mathrm{mg} / \mathrm{mL})$ prepared in ethanol, $1 \mathrm{~mL}$ of aluminium chloride, $1 \mathrm{~mL}$ of potassium acetate and $5.6 \mathrm{~mL}$ of distilled water were added. The mixture was incubated at $25{ }^{\circ} \mathrm{C}$ for 30 minutes. Absorbance of the reaction mixture was measured at $420 \mathrm{~nm}$ with the spectrophotometer. Quercetin was used as standard at different concentrations $(0-1000 \mu \mathrm{g} / \mathrm{mL})$ for the calibration curve. The analyses were performed in triplicate and the amount of flavonoids in extracts was calculated and expressed in $\mu \mathrm{g}$ equivalent quercetin/mg of extract obtained from the calibration curve.

\subsection{Ant-lipid Peroxidation Effects of Citrus sinensis, Allium sativum and Persea americana Extracts}

Anti-lipid peroxidation of plant extracts was assessed as described by Prasanth, Shasidhara \& Sridhara (2000). Firstly, a liver was isolated, dissected from a Wistar rat and washed in $\mathrm{NaCl}(0.9 \%)$; then cut into pieces, ground and mixed in $10 \%(\mathrm{w} / \mathrm{v})$ of phosphate buffer $0.1 \mathrm{M}, \mathrm{pH}$ 7.4. Three hundred (300) $\mu \mathrm{L}$ of extract prepared at various concentrations $(250,500,750$ and $1000 \mu \mathrm{g} / \mathrm{mL}$ ) were added to $500 \mu \mathrm{L}$ of liver homogenate. The mixture was incubated with $100 \mu \mathrm{L}$ of $\mathrm{NaCl}$ and the lipid peroxidation was initiated by addition of $100 \mu \mathrm{L}$ of a ferric sulfate $(15 \mathrm{mM})$ solution. The mixture was incubated at $37^{\circ} \mathrm{C}$ for $30 \mathrm{~min}$. One (1) $\mathrm{ml}$ of equal volume of TBA $(1 \%) / \mathrm{Hcl}(10 \%)$ was added to the solution followed by the addition of $1 \mathrm{ml}$ of ascorbic acid $(6 \mathrm{mM})$. The final mixture was heated at $80{ }^{\circ} \mathrm{C}$ for $20 \mathrm{~min}$ in a hot water bath. After $30 \mathrm{~min}$, the tubes were cooled in water for 10 min and centrifuged at $800 \mathrm{~g}$ for $15 \mathrm{~min}$. Absorbance was read at $532 \mathrm{~nm}$ against the blank consisting of reagents. The percentage inhibition of lipid peroxidation was calculated using the formula:$$
\text { Inhibition }(\%)=\frac{\text { Absorbance of Control }- \text { Absorbance of Sample }}{\text { Absorbance of Control }} \times 100
$$ \\ 2.5 Anti-hemolytic Activity of Citrus sinensis, Allium sativum and Persea americana Extracts}

Anti-hemolytic activity of plant extracts was assessed as described by Arbos, Claro, Borges, Santos \& Weffort-Santos (2008) with modifications. Measurement was done based on radical- induced erythrocyte lyses using an extract concentration of $1 \mathrm{mg} / \mathrm{mL}$ only. A human blood sample was purchased from blood bank of the University Teaching Hospital (CHU), Yaounde, Cameroon. Three milliter $(3 \mathrm{~mL})$ of blood was collected from the sample and centrifuged, the supernatant was discarded and red blood cell suspension used for anti-hemolytic assay. A volume of $0.2 \mathrm{~mL}$ of extract was mixed with $1 \mathrm{~mL}$ of $\mathrm{NaCl}(0.9 \%)$. To the mixture, was added $0.1 \mathrm{~mL}$ of red blood cell suspension, then incubated at room temperature for $30 \mathrm{~min}$. Then, $0.1 \mathrm{~mL}$ of CuSO $4(0.1 \mathrm{M})$ was added to induce haemolysis via oxidative degradation of the cell membrane. After 30 min of incubation, absorbance was read at $532 \mathrm{~nm}$ against a blank $(1.3 \mathrm{~mL}$ of NaCl and $0.1 \mathrm{~mL}$ of red blood cell suspension). Complete haemolysis (control) was achieved by mixing $0.2 \mathrm{~mL}$ of $\mathrm{NaCl}(0.9 \%), 0.1 \mathrm{~mL}$ of the $\mathrm{RBC}$ suspension and $1.1 \mathrm{~mL}$ of distilled water. The level of protection of RBC cell membrane by extracts was calculated using the formula:

$$
\text { Protection level }(\%)=\frac{\text { Absorbance of Control }- \text { Absorbance of Sample }}{\text { Absorbance of Control }} \times 100
$$

\subsection{Determination of Radical Scavenging Capacities}

The radical scavenging capacities (RSC) of different crude extracts were evaluated against $\mathrm{DPPH}^{\bullet}, \mathrm{ABTS}^{+}, \mathrm{NO} \bullet$ radicals as previously described by Azantsa et al., (2017a).

\subsubsection{DPPH• Scavenging Assay}

$\mathrm{DPPH} \bullet \mathrm{RSC}$ assay was based on measurement of the loss of DPPH• color after reaction with test compounds. The DPPH• scavenging activity was measured as reported by Katalinié, Milos, Modun, Musi \& Boban (2004). Fifty microliters $(50 \mu \mathrm{L})$ of the extract at different concentrations $(2.5,5.0,7.5$ and $10 \mathrm{mg} / \mathrm{mL})$ were introduced in $1.950 \mathrm{~mL}$ of an ethanolic solution of DPPH. After 30 minutes of incubation in the dark, the absorbance was 
measured at $515 \mathrm{~nm}$ against the blank consisting of reagent. Tests were done in triplicate. RSC was expressed as percentage inhibition and calculated by the following formula:

$$
\text { Inhibition }(\%)=\frac{\text { Absorbance of Control }- \text { Absorbance of Sample }}{\text { Absorbance of Control }} \times 100
$$

\subsection{2 $\mathrm{ABTS}^{+}$Scavenging Assay}

The ABTS-RSC was measured according to a modified procedure reported by Re et al. (1999). One hundred microliters $(100 \mu \mathrm{L})$ of the extract at different concentrations $(2.5,5,7.5$ and $10 \mathrm{mg} / \mathrm{mL})$ was introduced in test tubes, followed by $1000 \mu \mathrm{L}$ of $\mathrm{ABTS}^{+}$reagent, then incubated for 30 minutes in the dark. The absorbance was then read at $734 \mathrm{~nm}$ against the blank consisting of reagents. Tests were carried out in triplicates. RSC was calculated by the following formula:

$$
\text { Inhibition }(\%)=\frac{\text { Absorbance of Control }- \text { Absorbance of Sample }}{\text { Absorbance of Control }} \times 100
$$

\subsubsection{Nitric Oxide (NO•) Scavenging Assay}

NO-RSC was evaluated by measuring the accumulation of nitrite (formed by the reaction of NO with oxygen).The scavenging activity of extracts on nitric oxide was evaluated using the method of Sreejayan and Rao (1997). Two (2) $\mathrm{ml}$ of sodium nitroprusside (10mM) dissolved in phosphate buffer saline ( $\mathrm{pH}$ 7.4) was mixed with $1 \mathrm{~mL}$ of extract at various concentrations $(0.25-1 \mathrm{mg} / \mathrm{mL})$. The mixture was then incubated at $25^{\circ} \mathrm{C}$. After $15 \mathrm{~min}$ incubation, $0.5 \mathrm{~mL}$ of the incubated solution was pipetted and mixed with $1 \mathrm{~mL}$ sulfanilic acid $(0.33 \%$ in $20 \%$ acetic acid) at $25^{\circ} \mathrm{C}$ for 5 minutes, followed by the addition of $1 \mathrm{~mL}$ of naphthylethylenediamine dichloride $(0.1 \% \mathrm{w} / \mathrm{v})$. The mixture was then incubated at room temperature for $30 \mathrm{~min}$ and its absorbance read at $540 \mathrm{~nm}$. Test were carried out in triplicate. RSC was calculated by the following formula:

$$
\text { Inhibition }(\%)=\frac{\text { Absorbance of Control }- \text { Absorbance of Sample }}{\text { Absorbance of Control }} \times 100
$$

\subsection{Antioxidant Activities}

\subsubsection{Total Antioxidant Capacity (TAC)}

This reduction mechanism was evaluated using the method described by Prieto, Pineda \& Aguilar (1999).The extract $(0.2 \mathrm{~mL})$ prepared in ethanol was mixed with $2 \mathrm{~mL}$ of the reagent $(0.6 \mathrm{M}$ of sulphuric acid, $28 \mathrm{mM}$ of sodium phosphate and $4 \mathrm{mM}$ of ammonium molybdate). All the tubes were sealed and incubated at $95{ }^{\circ} \mathrm{C}$ for 90 min. After cooling the tubes, the absorbance of the solutions were measured at $695 \mathrm{~nm}$ against the blank containing $2 \mathrm{~mL}$ of the reagent and $0.2 \mathrm{~mL}$ of ethanol. The total antioxidant capacity was expressed in milligram equivalents of ascorbic acid per gram of dry materials (mg EAA/ $g$ dry materials).

\subsubsection{Determination of Inhibitory Concentration $50\left(\mathrm{IC}_{50}\right)$}

The concentration (in the final reaction media) that causes a decrease of initial absorbance (control) by $50 \%$ is defined as $\mathrm{IC}_{50}$. The $\mathrm{IC}_{50}$ values for all $\mathrm{RSC}$ were determined by regression of the inhibition values.

\subsection{Statistical Analyses}

Data were expressed as the averages of triplicate analyses and as mean \pm standard deviation and as percentages. The statistical package for social science (SPSS) 20.0 (Chicago-Illinois Inc.) was used. One-way ANOVA followed by post-hoc Tukey's test was performed to compare variable amongst groups. Chi square test was used to compare percentages. Results with a $p<0.05$ were considered significant. Using GraphPad Prism 6.0 (GraphPad Prism INC., CA, USA), logarithm of the extract concentration was plotted against RSC to obtain a nonlinear regression curve -fitting and a variable slope to determine $\mathrm{IC}_{50}$.

\section{Results}

\subsection{Determination of Total Polyphenols and Flavonoids Content}

Polyphenols were higher in Allium sativum and Citrus sinensis than Persea americana seed. There were more flavonoids in Allium sativum and Persea americana than Citrus sinensis (Table 1). 
Table 1. Total Polyphenolic and flavonoids content of different extracts

\begin{tabular}{llll}
\hline Plants extracts & Bark of Citrus sinensis & Allium sativum bulbs & Persea americana seeds \\
\hline Polyphenols $(\mu \mathrm{g} \mathrm{d} E C / \mathrm{mL})$ & $208.89 \pm 25.24^{\mathrm{a}}$ & $211.11 \pm 15.40^{\mathrm{a}}$ & $1082.22 \pm 17.33^{\mathrm{b}}$ \\
Flavonoids $\left(\mu \mathrm{g} d^{\prime} \mathrm{EQue} / \mathrm{mL}\right)$ & $0.85 \pm 0.05^{\mathrm{a}}$ & $3.70 \pm 0.31^{\mathrm{b}}$ & $2.09 \pm 0.08^{\mathrm{c}}$ \\
\hline
\end{tabular}

Results are expressed as Mean \pm Standard Deviation; EQu: equivalent quercetin; EC: equivalent catechin. EA: aqueous extract; Values with different letters a,b, c assigned are significantly different $(\mathrm{p}<0.05)$.

\subsection{Anti-lipid Peroxidation of Citrus sinensis, Allium sativum and Persea americana}

All the extracts protected liver homogenates against lipid peroxides. A. sativum and Citrus sinensis showed moderate inhibitory effects on lipid peroxidation. Extracts from $P$. americana showed the highest $(\mathrm{p}<0.05)$ inhibition with increasing concentrations (from 53.37 to 59.88\%) (Figure 1).

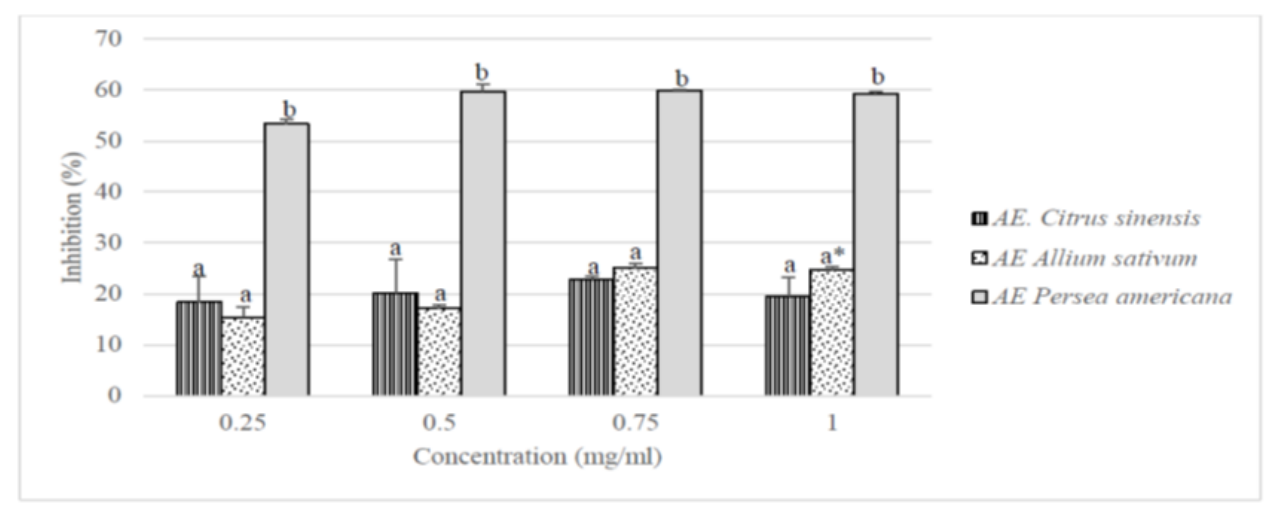

Figure 1. Inhibitory activity of extracts on lipid peroxidation

Graph bar with different letters a,b, c assigned are significantly different $(\mathrm{p}<0.05)$; *: $\mathrm{p}<0.05$ compared to the lowest concentration

\subsection{Anti-hemolytic Activity of Citrus sinensis, Allium sativum and Persea americana extracts}

Protective effect of Allium sativum against red blood cell lysis (anti-hemolytic activity) was higher $(\mathrm{p}<0.05)$ than Persea americana and bark of $C$. sinensis extract. Allium sativum protected RBC at $97.7 \%$, while Citrus sinensis protected at $87.7 \%$ (Figure 2).

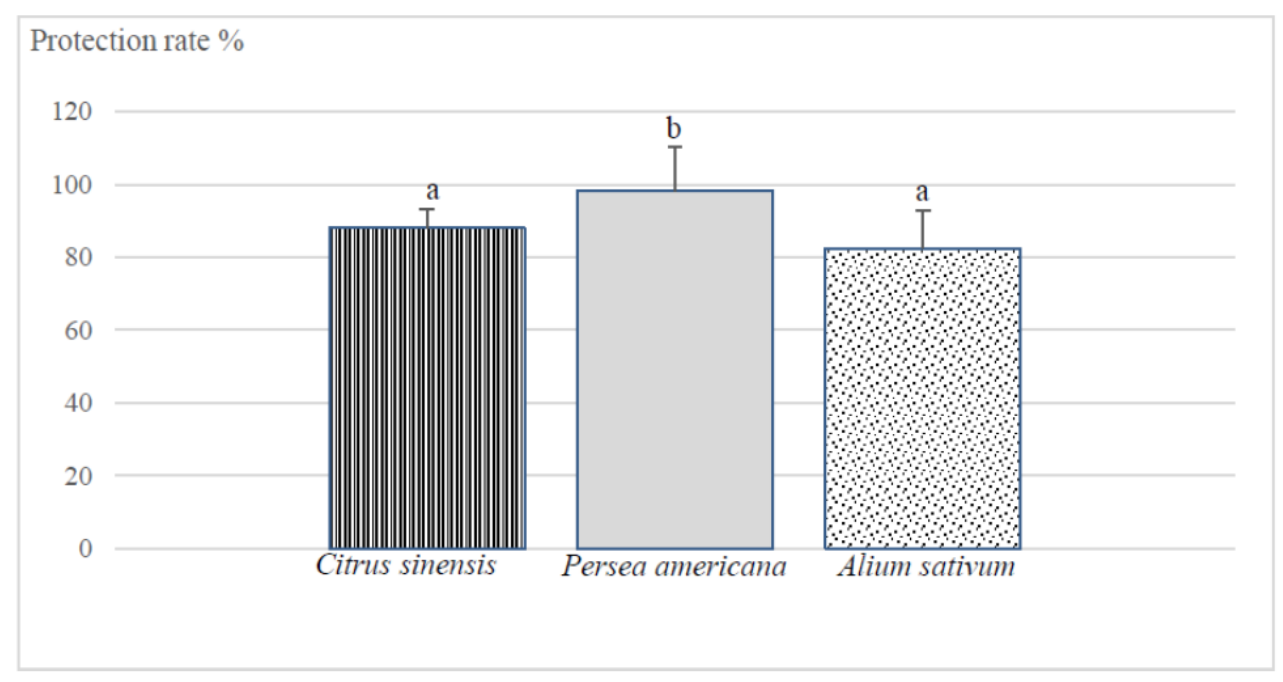

Figure 2. Anti-hemolytic activity of extracts

Results are expressed as Mean $\pm \mathrm{SD}$. Experiment done in triplicate. Bar graphs with different letters $a, b$ represent significant difference $(\mathrm{p}<0.05)$ amongst extracts of the different plant. 


\subsection{Scavenging Effects of Extracts on DPPH Radical}

All extracts showed inhibition of DPPH free radical in a dose dependent manner. Persea americana displayed the best values from $47.48 \%$ at the lowest concentration to $80 \%$ at the highest concentration of extracts. They were followed by Citrus sinensis and the lowest percentage of inhibition was observed with Allium sativum (Figure 3).

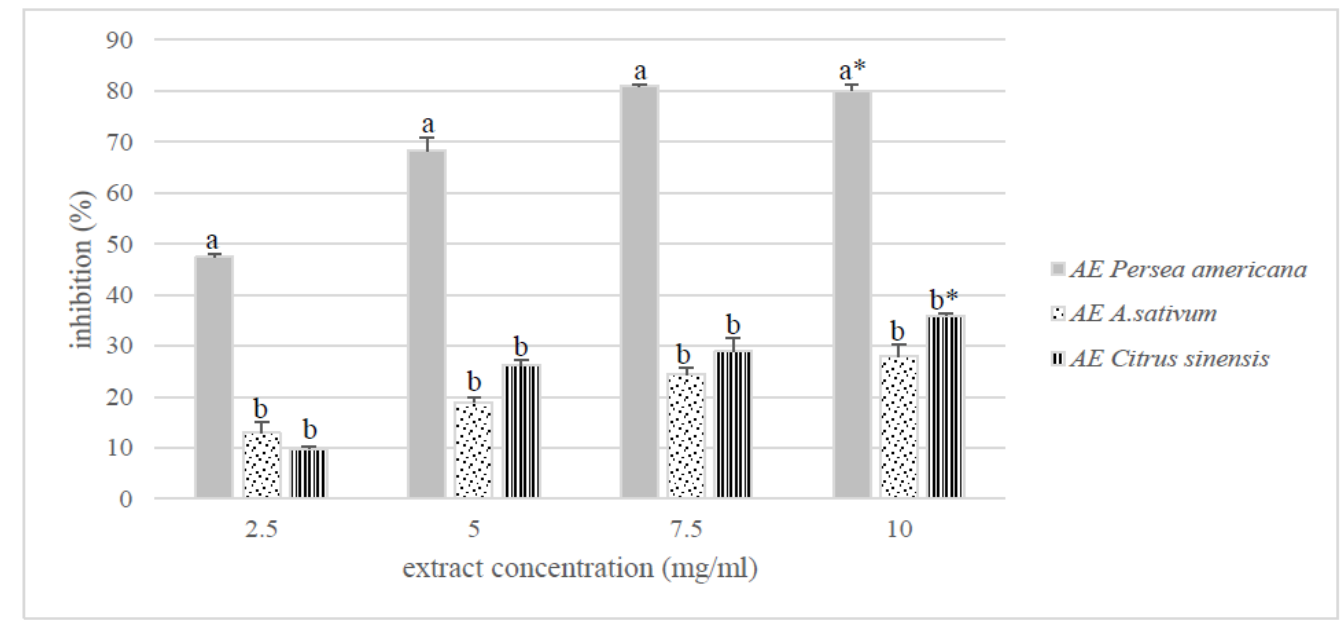

Figure 3. Inhibition of DPPH radical by aqueous extracts

Results are expressed as Mean \pm SD. Experiment done in triplicate. Bar graphs with different letters $a, b$ represent significant difference $(\mathrm{p}<0.05)$ amongst extracts of the different plants

Inhibitory concentration 50 of all the extracts revealed that $2.30 \mathrm{mg} / \mathrm{ml}$ of Persea americana was able to produce $50 \%$ inhibition of DPPH radicals generated (Table 2).

\subsection{Scavenging Effect of Extracts on ABTS Radical}

Only two extracts inhibited $\mathrm{ABTS}^{+}$radical. Persea americana was very active on $\mathrm{ABTS}^{+}$free radicals scavenging up to $97 \%$ at the lowest dose of $2.5 \mathrm{mg} / \mathrm{ml}$. However, Citrus sinensis (AEC s) displayed null inhibition percentage at the tested concentrations (Figure 4).

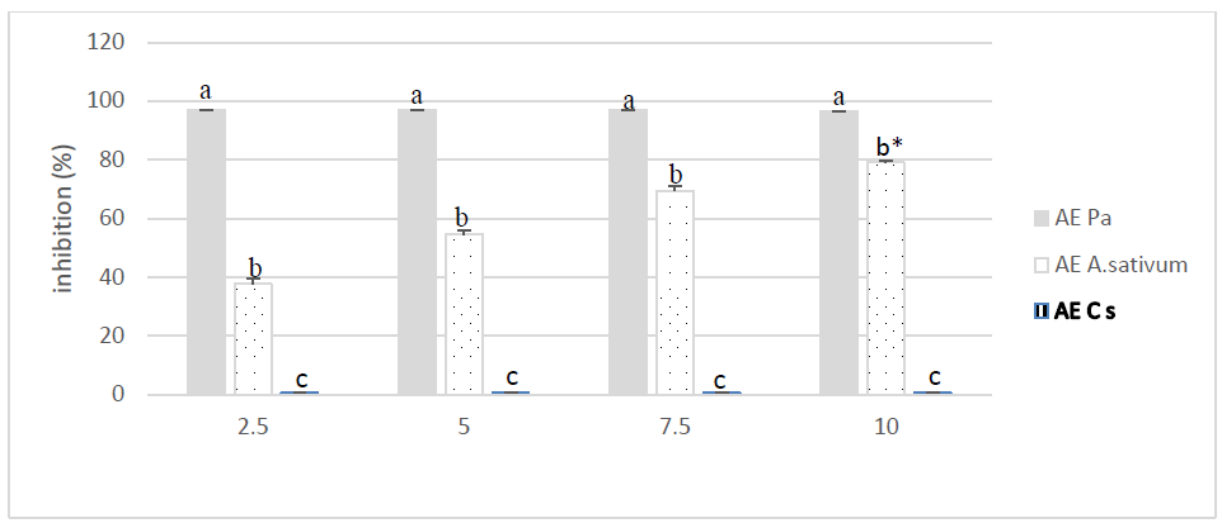

Figure 4. Scavenging effect of extracts on ABTS radical

Results are expressed as Mean \pm SD. Experiment done in triplicate. Bar graphs with different letters a,b, c represent significant difference $(\mathrm{p}<0.05)$ amongst extracts of the different plants; *: $\mathrm{p}<0.05$ compared to the lowest concentration.

Concentration of extracts capable of scavenging $50 \%$ of the ABTS free radicals were found with AE of $P$. americana, with the lowest $\mathrm{IC}_{50}=1.02 \times 10^{-3} \mathrm{mg} / \mathrm{mL}$ compared to $\mathrm{AE}$ of Allium sativum $\left(\mathrm{IC}_{50}=\right.$ of 60.10 $\mathrm{mg} / \mathrm{mL}$ ). 


\subsection{NO Scavenging Activity of Extracts}

The extracts of A. sativum and Persea americana demonstrated higher inhibition against NO radical, as shown in Figure 5. The results expressed as percentage of inhibition varied as follows: $43.19(0.25 \mathrm{mg} / \mathrm{mL})$ to $55.54 \%$ (1 $\mathrm{mg} / \mathrm{mL}$ ) for aqueous extract.

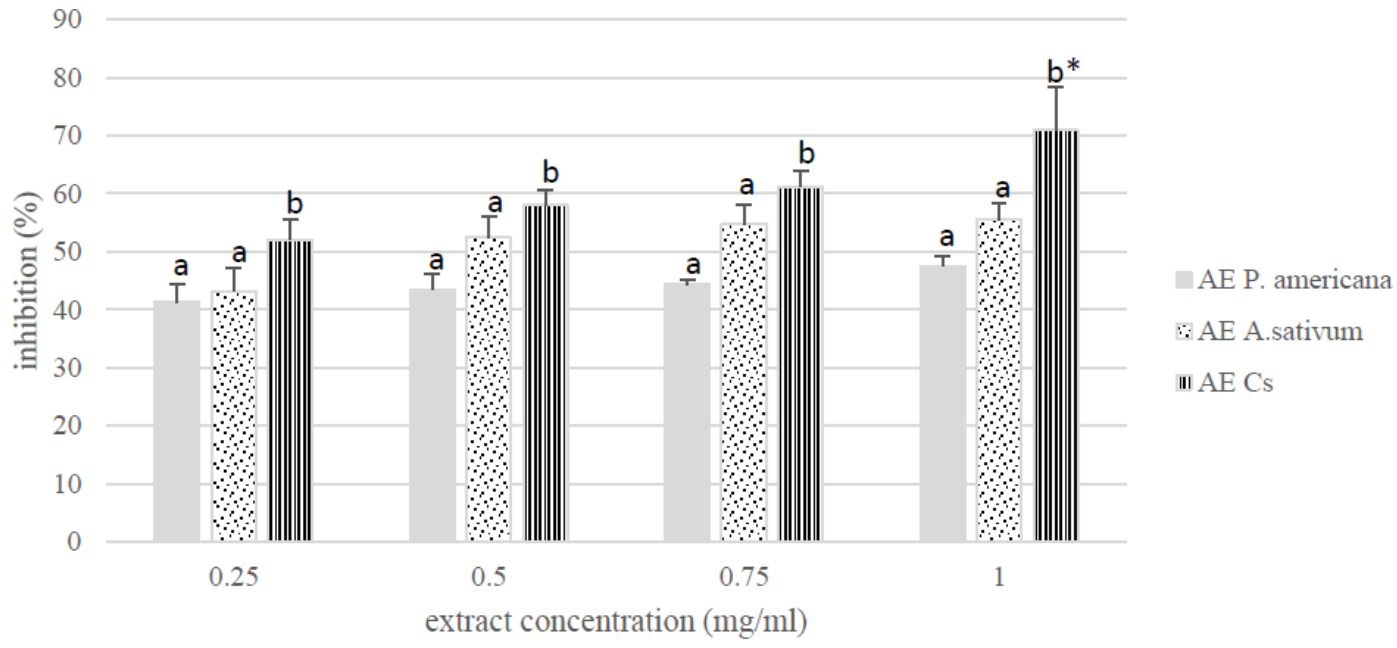

Figure 5. NO scavenging activity of different extracts

Results are expressed as Mean \pm SD. Bar graphs with different letters a,b, c represent significant difference $(p<0.05)$ amongst extracts of the different plants; $* \mathrm{p}<0.05$ compared to the lowest concentration. AECs: Aqueous extracts of Citrus sinensis

The results expressed as percentage of inhibition varies as follows: $41.27(0.25 \mathrm{mg} / \mathrm{mL})$ to $47.54 \%(1 \mathrm{mg} / \mathrm{mL})$ for aqueous extract. Compared to the other extracts, Allium sativum had the lowest $\mathrm{IC}_{50}(0.14 \mathrm{mg} / \mathrm{mL})$ compared to other extracts (Table 2).

\section{7 $\mathrm{OH}$ Scavenging Activity of Extracts}

Citrus sinensis was able to scavenge $\mathrm{OH}$ radical at $45 \%$. Percentage inhibitions were higher at lower dose < $0.75 \mathrm{mg} / \mathrm{ml}$ and lower at higher dose except for P. americana (Figure 6). Aqueous extracts of P. americana seed demonstrated highest ability to scavenge $\mathrm{OH}$ radical in vitro. Values varied from $44.3 \%(0.5 \mathrm{mg} / \mathrm{mL})$ to $40.9 \%$ $(0.5 \mathrm{mg} / \mathrm{mL})$.

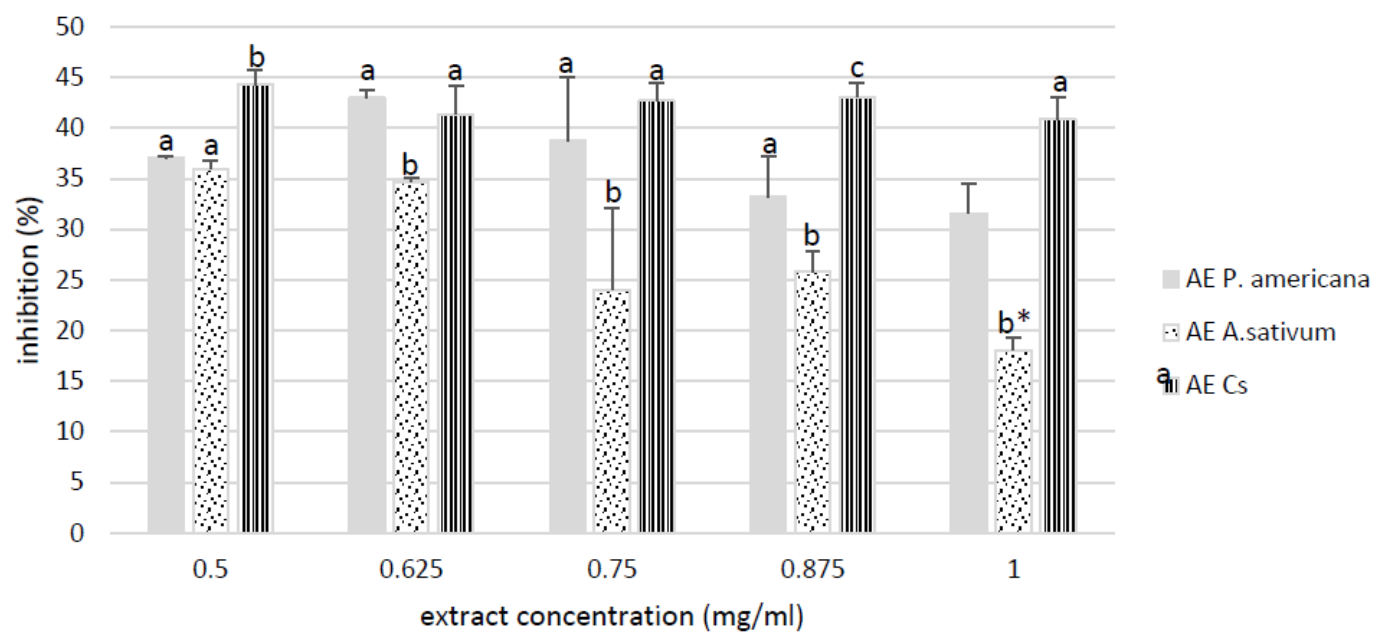

Figure 6. scavenging activities of extracts on $\mathrm{OH}$ Radicals

Results are expressed as Mean \pm SD. Bar graphs with different letters a,b, c represent significant difference $(p<0.05)$ amongst extracts of the different plants; $* \mathrm{p}<0.05$ compared to the lowest concentration; AECs: Aqueous extracts of Citrus sinensis 
Concentration of extracts capable of scavenging $50 \%$ of free radicals are summarized in Table 2. It appears that Allium sativum displayed the lowest $\mathrm{IC}_{50}=4.57 \times 10^{-4} \mathrm{mg} / \mathrm{mL}$ against $\mathrm{OH}$ radicals and the $\mathrm{AE}$ of $P$. americana $\left(\mathrm{IC}_{50}=6.27 \times 10^{-4} \mathrm{mg} / \mathrm{mL}\right.$ ), the poorer on NO radicals. (Table 2).

Table 2. Inhibitory concentration $\left(\mathrm{IC}_{50}\right)$ values for assays

\begin{tabular}{llll}
\multirow{2}{*}{ Radicals } & Extracts & \multicolumn{3}{l}{ Inhibitory Concentration- IC50 $(\mathbf{m g} / \mathbf{m l})$} \\
\cline { 2 - 4 } & Allium sativum & Persea americana & Citrus sinensis \\
\hline DPPH & 124.80 & 2.30 & 8.22 \\
ABTS & 60.10 & $1.02 \times 10^{-3}$ & 0 \\
NOo & 0.14 & $6.12 \times 10^{4}$ & $1.05 \times 10^{-3}$ \\
OHo & $4.57 \times 10^{-4}$ & $6.27 \times 10^{-4}$ & $1.29 \times 10^{-3}$ \\
\hline
\end{tabular}

\subsection{Determination of the Total Antioxidant Capacity of Extracts}

Total antioxidant capacity increases with increasing concentrations in all extracts, varying from 0.7-1.5 respectively for lower and higher dose $(1 \mathrm{mg} / \mathrm{mL})$. At all doses, Persea americana and Allium sativum were higher than Citrus sinensis. Extracts of A. sativum showed the highest total antioxidant capacity with increasing concentrations of extracts. The results expressed as equivalent ascorbic acid varies as follows: $0.70(0.5 \mathrm{mg} / \mathrm{ml})$ to $1.51 \mu \mathrm{g} \mathrm{EAA} / \mathrm{mL}(1 \mathrm{mg} / \mathrm{ml})$ for aqueous extract and $1.56 \mu \mathrm{g} \mathrm{EAA} / \mathrm{mL}(1 \mathrm{mg} / \mathrm{ml})$ for aqueous extract.

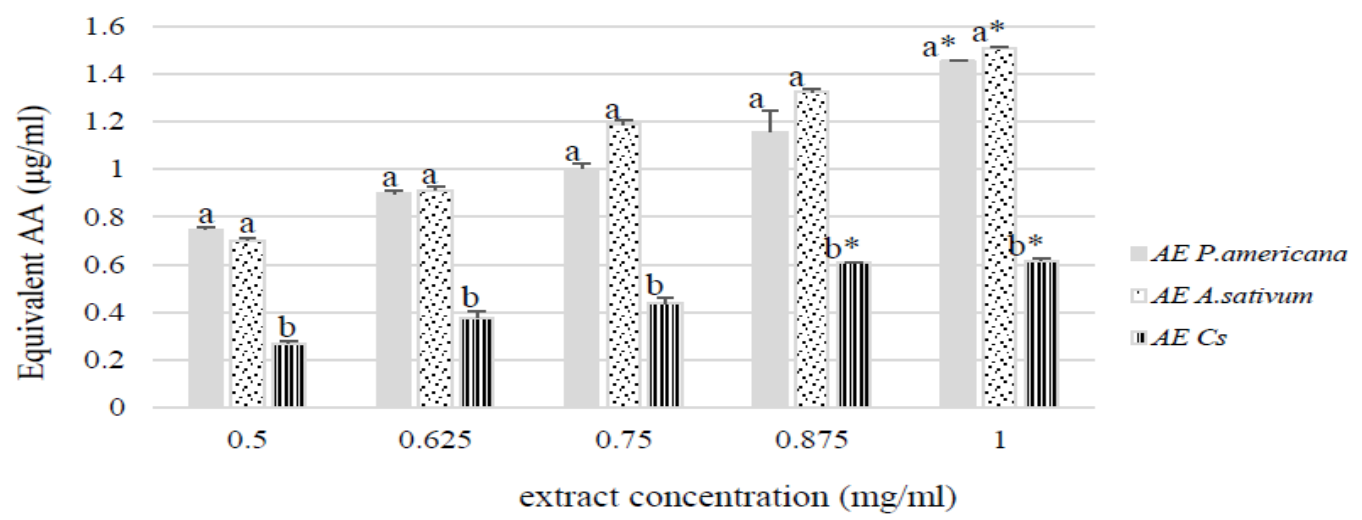

Figure 7. Total antioxidant capacity of plant extracts

Results are expressed as Mean \pm SD. Bar graphs with different letters a,b, c represent significant difference $(\mathrm{p}<0.05)$ amongst extracts of the different plants; $* \mathrm{p}<0.05$ compared to the lowest concentration. AECs: Aqueous extracts Citrus sinensis

\section{Discussion}

Plants, herbs and spices have been reported to have curative effects on type 2 diabetes and metabolic syndrome (Kuate, Nouemsi, Biapa, Azantsa \& Wan, 2015; Kooti et al., 2016, Matsinkou, Dakam, Azantsa, Ngondi and Oben, 2017). Hypoglycemic, anti-obesity and anti-oxidant capacities of Persea americana, Allium sativum and Citrus sinensis have been reported (Eyo, Ozougwu \& Echi, 2011; Smitha, Jyoti \& Chaithra, 2016). Toxicity studies have proven them safe as well (Yasir et al., 2010). However, mechanisms by which they act are not yet fully understood. Free radicals are generated in T2DM due to hyperglycemia. Prolonged hyperglycemia leads of depletion of enzymatic and non-enzymatic antioxidants (Weseler and Bast, 2010). Reactive oxygen and nitrogen species (RONS) attack various organs and alter their function. Oxidative damages on membrane of red blood cells, used as a suitable and simplest model system for elucidation of redox mechanisms in this study showed that Allium sativum extracts provide greatest protection (97.7\%), preventing lysis and hemolysis compared to Persea americana seed and Citrus sinensis (Figure 2). Because of the absence of nuclei, ribosomes and mitochondria coupled to lack of protein synthesis and mitochondria based oxidative reactions in mammalian $\mathrm{RBC}$, the protection rate observed reflects direct interaction with the membrane (Youn et al., 2017; Zohra \& Atik, 2014). Hemolysis which is therefore the result of necrosis and destruction of bilayer membrane due to deformability of its shape (Youn et al., 2017) caused by hyperglycaemia sometimes interferes with glycosylated hemoglobin (Hb1Ac) levels, very important in the diagnosis. Allium sativum protects cell membranes, preventing alteration of lipids and proteins. ROS cause lipid peroxidation and protein alterations of functions 
which contribute towards Diabetes Mellitus and its complications including neuropathy, retinopathy, stroke, endothelial dysfunctions, insulin resistance and dyslipidemia (Phillips, Cataneo, Cheema,\& Greenberg, 2004; Asfandiyarova, Kolcheva, Ryazantsev, \& Ryazantsev, 2007). Furthermore, ROS and RNS interfere with physiological processes in cells (Wesler \& Bast, 2010; Omale and Alewo, 2014). Persea americana seeds were capable to scavenge and inhibit lipid peroxidation more than Allium sativum and Citrus sinensis (Figure 1) preserving cells integrity. The anti-lipid peroxidation effect observed with Persea americana can be attributed to polyphenol content which was higher in P. americana compared to Citrus sinensis stem bark and Allium (Table 1). Evidences reported strong positive correlations between polyphenols and total antioxidant capacity. Also, strong negative correlations have been proven between DPPH radical and polyphenol contents of plants (Vaya et al., 2003; Ramchoun et al, 2015; Azantsa et al., 2017a). The efficacy of plants resides in their scavenging ability. Citrus sinensis extracts and Persea americana scavenged $\mathrm{OH}$ radicals than NO radicals (Figure 3). Allium sativum extracts scavenged ABTS radical than Citrus sinensis that showed no activity on ABTS at the measured concentrations of extracts (Figure 4). However, all the extracts displayed high total antioxidant capacity with highest values observed with Allium sativum and Persea Americana (Figure 7). Antioxidants from all plants reduced lipid peroxidation and inhibited production of free radicals OH and NO, DPPH, ABTS as earlier demonstrated by El-Bahr (2013). Action of phenolic compounds are based on redox ability of their phenolic hydroxyl groups (Velioglu, Mazza, Gao, \& Oomah 1998; Ramchoun et al, 2015). Different plants showed variable inhibition levels depending on free radical sources. Polyphenolic compounds and flavonoids found in extracts (Table 1) play a crucial role in the protection of RBC from oxidative damages, preventing hemolysis through scavenging action of free radicals, ROS and RNS (Khalili, Mohammad, \& Yaghoub, 2014; Audomkasok, Warapom, Sukanya \& Voravuth, 2014).

\section{Conclusions}

Aqueous extracts of C. sinensis, A. sativum and P. americana possess total antioxidant capacity and can scavenge free radicals at various extends. The aqueous extract of Citrus sinensis stem bark is a powerful scavenger of biological free radical $\mathrm{OH}$ and NO. Persea americana seeds powerfully prevent lipid peroxidation and are efficient against ABTS and DPPH radicals. Allium sativum extract provided highest protection against hemolysis from radical induced red blood cells lysis. Given that different extracts seem to be efficient on different targets, a formulation based on $C$. sinensis, A. sativum and $P$. americana could be envisaged to manage diabetes and metabolic syndrome.

\section{References}

Afsar, T., Suhail, R., Muhammad, R. K., Saadia, M., Ali, A., Maria, S., \& Ihsan, U. H. (2016). Evaluation of antioxidant, anti-hemolytic and anticancer activity of various solvent extracts of Acacia hydaspica R. Parker aerial parts. BMC Complement Altern Med, 16, 258. https://doi.org/10.1186/s12906-016-1240-8

AlSalhi, M. S., Sandhanasamy, D., Khalid, E. A., Mashael, A., Fatima, A-Q., Karim, F., \&Vadivel, M. (2018). Impact of Diabetes Mellitus on Human Erythrocytes: Atomic Force Microscopy and Spectral Investigations. Int. J. Environ. Res. Public Health, 15, 23-68. https://doi.org/10.3390/ijerph15112368

Aiyegoro, O. A., \& Okoh, A. I. (2010). Preliminary phytochemical screening and in vitro antioxidant activities of the aqueous extract of Helichrysum longifolium. BMC Complement Alternative Medicine, 10, 21-32. https://doi.org/10.1186/1472-6882-10-21

Antia, B., Okokon, J., \& Okon, P. (2005). Hypoglycemic activity of aqueous leaf extract of Persea americana Mill. Research Letter, 37(5), 325-326. https://doi.org/10.4103/0253-7613.16858

Arbos, K. A., Claro, L. M., Borges, L., Santos C. A. M., \& Weffort-Santos, A. M. (2008). Human erythrocytes as a system for evaluating the antioxidant capacity of vegetable extracts. Nutr Res, 28, 457-463. https://doi.org/10.1016/j.nutres.2008.04.004

Arukwe, U., Amadi, B., Duru, M., Agomuo, E., Adindu, E., Odika, P., Lele, K., Egejuru, L., \& Anudike, J. (2012). Chemical composition of Persea americana leaf,fruit and seed. IJRRAS, 11(2), 346-349.

Asfandiyarova, N., Kolcheva, N., Ryazantsev, I., \& Ryazantsev, V. (2007). Risk factors for stroke in type 2 diabetes mellitus. Diab. Vasc. Dis. Res, 3, 57-60. https://doi.org/10.3132/dvdr.2006.009

Asmat, U., Khan, A., \& Ismail, K. (2016). Diabetes mellitus and oxidative stress-A concise review. Saudi Pharmaceutical Journal, 24(5), 547-553. https://doi.org/10.1016/j.jsps.2015.03.013

Audomkasok, S., Warapom, S., Sukanya, C., \& Voravuth, S. (2014). Antihemolytic Activities of Green Tea, Safflower, and Mulberry Extracts during Plasmodium. berghei Infection in Mice. Journal of Pathogens. 
https://doi.org/10.1155/2014/203154

Azantsa, K. G. B., Djuikoo, N. I., Kuikoua, T. W., Takuissu, G., Judith, L. N., \& Julius, O. (2017). Phytochemical Screening and Anti-diabetic Evaluation of Citrus sinensis Stem Bark Extracts. International Journal of Biochemistry Research \& Review, 17(2), 1-13. https://doi.org/10.9734/IJBCRR/2017/34051

Azantsa, K. G. B., Djuikoo, N. I., Takuissu, G., Kuikoua, T. W., Temdemnou, E., Judith, L. N., \& Oben, J. (2017a). Antioxidant Activity of Leaves' Extracts of Citrus Sinensis:Determination of Radical Scavenging Capacity, Antiradical Power, Total Polyphenols and Flavonoids Content. Am. J. Pharm Health Res, 5(5), 100-117.

Azantsa, K. G. B., Tchetmi, K., Takuissu N. G., Takwi, E. M., Tagne, M. V., Ngondi J. L., \& Oben J. (2018). Effects of Polyherbal Formulation of Allium sativum and Persea americana seeds' Extracts on Postprandial Hyperglycaemia and Sucrose Digestion in Acute Treatment of Normoglycemic Rats. Biology and Medicine (Aligarh), 10, 432.

Bayan, L., Koulivand, P., \& Gorji, A. (2014). Garlic: a review of potential therapeutic effects. Avicenna $J$ Phytomed, 4(1), 1-14.

Boadi, O., Saah, S., Mensah, J., Badu, M., Addai-Arhinand, S., \& Mensah, M. (2015). Phytoconstituents, antimicrobial and antioxidant properties of the leaves of Persea americana Mill cultivated in Ghana. J. Med. Plants, 9(36), 933-939. https://doi.org/10.5897/JMPR2015.5902

Bordoloi, R., \& Dutta, K. (2014). A Review on Herbs Used in the Treatment of Diabetes mellitus. J. Pharm. Chem. Biol. Sci, 2(2), 86-92.

Borek, C. (2001). Antioxidant health effects of aged garlic extract. J Nutr, 131, 1010S-5S. https://doi.org/10.1093/jn/131.3.1010S

Dreher, M., \& Davenport, A. (2013). Hass Avocado Composition and Potential Health Effects. Critical Reviews in Food Science and Nutrition, 53, 738-750. https://doi.org/10.1080/10408398.2011.556759

Ebrahimzadeh, M., Nabavi, S., \& Nabavi, S. (2009). Antioxidant activities of methanol extract of Sambucus Ebulus L. Flower Pak. J Biol Sci, 12(5), 447. https://doi.org/10.3923/pjbs.2009.447.450

Eidi, A., Eidi, M., \& Esmaeili, E. (2006). Antidiabetic effect of garlic (Allium sativum L.) in normal and streptozotocin-induced diabetic rats. Phytomedicine, 13(9), 624-9. https://doi.org/10.1016/j.phymed.2005.09.010

El-Bahr, S. (2013). Biochemistry of Free Radicals and Oxidative Stress. Science International, 1, 111-117. https://doi.org/10.5567/sciintl.2013.111.117

Etebu, E., \& Nwauzoma A., (2014). A review on sweet orange (Citrus Sinensis Osbeck): health, diseases, and management. American Journal of Research Communication, 2(2), 33-70

Eyo, J., Ozougwu, J., \& Echi, P. (2011). Hypoglycemic effects of Allium cepa, Allium sativum and Zinger officinale aqueous extracts on alloxan induced-diabetic rattus norvergicus. Medical Journal of Islamic World Academy of Sciences, 19(3), 121-126.

Huzaifa, U., Labaran, I., Bello, A., \& Olatunde, A. (2014). Phytochemical Screening of Aqueous Extract of Garlic (Allium sativum) bulbs. Report and Opinion, 6(8), 1-4.

Kaiser, A. B., Nicole, Z., \& Wouter, V. D. P. (2018). Global Prevalence of Type 2 Diabetes over the Next Ten Years (2018-2028). Diabetes, 67 (Supplement 1). https://doi.org/10.2337/db18-202-LB

Kamagate, M., Kouame, N., \& Koffi, E. et al. (2016). Acute toxicity and hypoglycaemic activity of the leaf extracts of Persea americana Mill. (Lauraceae) in Wistar rats. African Journal of Pharmacy and Pharmacology, 10(33), 690-698. https://doi.org/10.5897/AJPP2016.4617

Katalinié, V., Milos, M., Modun, D., Musi, I., \& Boban, M. (2004). Antioxidant effectiveness of selected wines in comparison with (+) - catechin. Food Chemistry, 86, 593-600. https://doi.org/10.1016/j.foodchem.2003.10.007

Khalili, M., Mohammad, A. E., \& Yaghoub, S. (2014). Antihaemolytic activity of thirty herbalextracts in mouse red blood cells. Archives of Industrial Hygiene and Toxicology, 65(4), 399-406. https://doi.org/10.2478/10004-1254-65-2014-2513

Kooti, W., Maryam, F., Zahra, A., Damoon, A.-L., \& Majid, A-S. (2016). The role of medicinal plants in the treatment of diabetes: a systematic review. Electron Physician, 8(1), 1832-1842. 
https://doi.org/10.19082/1832

Kuate, D., Nouemsi, K. A., Cabral, P. N., Azantsa, K. G. B., \& Wan, A. M. M. (2015). Tetrapleura tetraptera spice attenuates high-carbohydrate, high-fat diet-induced obese and type 2 diabetic rats with metabolic syndrome features. Lipids in Health and Disease, 14, 50. https://doi.org/10.1186/s12944-015-0051-0

Kumala, S., Utami, H., \& Sari, W. (2013). The effect of avocado (Persea americana mill.) leaves extract towards the mouse's blood glucose decrease with the glucose tolerance method. IJPSR, 4(2), 661-665.

Kung, C., Tseng, Z., \& Wang, H. (2009). Erythrocyte fragility increases with level of glycosylated hemoglobin in type 2 diabetic patients. Clin Hemorheol Microcirc, 43(4), 345-51.

Leal, J. K. F., Merel, J. W. A-H., \& Giel, J. C. (2018). Red Blood Cell Homeostasis: Mechanisms and Effects of Microvesicle Generation in Health and Disease. Front. Physiol. https://doi.org/10.3389/fphys.2018.00703

Narendhirakannan, R., \& Rajeswari, K. (2010). In Vitro Antioxidant Properties of Three Varieties of Allium Sativum L. Extracts. E-Journal of Chemistry, 7(1), S573-S579. https://doi.org/10.1155/2010/283627

Matsinkou S. R., Dakam, W., Azantsa, K. G. B., Ngondi, J. L., \& Oben, J. (2017). Measurement of Antioxidant Activity of African Mango (Irvingia Wombolu) Kernel Peels. World Journal of Pharmaceutical Research, 6(4), 148-162. https://doi.org/10.20959/wjpr20174-8080

Omale, J., \& Alewo, I. M. (2014). In vitro antihemolytic activity of Gymnema sylvestre extracts against hydrogen peroxide $\left(\mathrm{H}_{2} \mathrm{O} 2\right)$ induced haemolysis in human erythrocytes. AJPCT, 2(7), 861-869.

Phillips, M., Cataneo, R. N., Cheema, T., \& Greenberg, J. (2004) Increased breath biomarkers ofoxidative stress in diabetes mellitus. Clin. Chim. Acta, 344(1-2), 189-194. https://doi.org/10.1016/j.cccn.2004.02.025

Prasanth, K. V., Shasidhara, S. K. M., \& Sridhara, B. (2000). Effect of Luffa echinata on lipid oxidation and free radical scavenging activity. Journal of Pharmacy and Pharmacology, 52(7), 891-894. https://doi.org/10.1211/0022357001774589

Prieto, P., Pineda, M., \& Aguilar, M. (1999). Spectrophotometric quantitation of antioxidant capacity through the formation of a phosphomolybdenum complex: specific application to the determination of vitamin $\mathrm{E}$. Analytical Biochemistry, 269(2), 337-341. https://doi.org/10.1006/abio.1999.4019

Ramchoun, M., Khalid, S., Hicham, H., Chakib, A., Mohamed, B., Farid, K., \& Souliman, A. (2015). Investigation of antioxidant and antihemolytic properties of Thymus satureioides collected from Tafilalet Region, south-east of Morocco. Asian PacificJournal of Tropical Biomedicine, 5(2), 93-100. https://doi.org/10.1016/S2221-1691(15)30151-9

Ranade, S., \& Thiagarajan, P. (2015). A Review on Persea americana Mill. (Avocado) - Its Fruit and Oil. Int.J. PharmTech Res, 8(6), 72-77.

Re, R., Pellegrini, N., Preoteggente, A., Pannala, A., Yang, M., \& Rice-Evans C. (1999). Antioxidant activity applying an improved ABTS radical cation decolorization assay. Free Radical Biology and Medecine, 9(10), 121-137. https://doi.org/10.1016/S0891-5849(98)00315-3

Rodrigo, R., Bächler, J. P., Araya, J., Prat, H., \& Passalacqua, W. (2007). Relationship between (Na+K)-ATPase activity, lipid peroxidation and fatty acid profile in erythrocytes of hypertensive and normotensive subjects. Mol. Cell. Biochem, 303, 73-81. https://doi.org/10.1007/s11010-007-9457-y

Singleton, V., \& Rosi, J. J. (1965). Colorimetry of total phenolics with phosphomolybdic phosphotungstic acid reagents. Am J Enol Vitic, 16(1965), 144-158.

Smitha, G., Jyoti, B., \& Chaithra, R. (2016). In vitro alpha amylase inhibitory effect and antioxidant activity by peel and seed extracts of Persea americana. Wjpls, 2(3), 261-269.

Sreejayan, \& Rao, M. (1997). Nitric oxide scavenging by curcuminoids. J. Pharm. Pharmacol, 49, $105-107$. https://doi.org/10.1111/j.2042-7158.1997.tb06761.x

Vaya, J., Mahmood, S., Goldblum, A., Aviramc, M., Volkova, N., Shaalan, A., Musa, R., \& Tamir, S. (2003). Inhibition of LDL oxidation by flavonoids in relation to their structure and calculated enthalpy. Phytochemistry, 62, 89-99. https://doi.org/10.1016/S0031-9422(02)00445-4

Velioglu, Y., Mazza, G., Gao, L., \& Oomah, B. (1998). Antioxidant activity and total phenolics in selected fruits, vegetables and grain products. J Agric Food Chem, 46(1998), 4113-4117. https://doi.org/10.1021/jf9801973a

Vinha, A., Moreira, J., \& Barreira, S. (2013). Physicochemical Parameters, phytochemical composition and 
antioxidant activity of the Algarvian Avocado (Persea Americana Mill.). Journal of Agricultural Science, 5(12), 1916-9752. https://doi.org/10.5539/jas.v5n12p100

Vinha, A., Moreira, J., \& Barreira, S. (2013) Physicochemical Parameters, Phytochemical Composition and Antioxidant Activity of the Algarvian Avocado (Persea americana Mill). The Journal of Agricultural Science, 5(12), 100-109. https://doi.org/10.5539/jas.v5n12p100

Viskupicova, J., Dusan, B., Sabina, G., Mirosław, S., Grzegorz, B., Lubica, H., \& Izabela S-B. (2015). Effect of high glucose concentrations on human erythrocytes in vitro glucose concentrations on human erythrocytes in vitro. Redox Biol, 5, 381-387. https://doi.org/10.1016/j.redox.2015.06.011

Weseler, A. R., \& Bast, A. (2010). Oxidative stress and vascular function: implications for pharmacologic treatments. Curr. Hypertension Rep, 12(3), 154-161. https://doi.org/10.1007/s11906-010-0103-9

Yasir, M., Das, S., \& Kharya, M. (2010). The phytochemical and pharmacological profile of Persea americana Mill. Pharmacoqn Rev, 4(7), 77-84. https://doi.org/10.4103/0973-7847.65332

Youn, K. B.,Yoon, H. H., Yong, H. K., Jeongho, K., Min., S. K., Hun-Kuk. P., Eun, H. C., \& Byoungchoo, P. (2017). The Role of Free Radicals in Hemolytic Toxicity Induced by Atmospheric-Pressure Plasma. Jet Oxidative Medicine and Cellular Longevity. https://doi.org/10.1155/2017/1289041

Young, I. C., Michael, P., Mooney, B. S., \& Daniel, J. C. (2008). Hemorheological Disorders in Diabetes Mellitus. J Diabetes Sci Technol, 2(6), 1130-1138. https://doi.org/10.1177/193229680800200622

Zohra, M., \& Atik, F. (2014). Hemolytic activity of different herbal extracts used in Algeria. International Journal of Pharma Sciences and Research (IJPSR), 5(8), 495-500.

\section{Copyrights}

Copyright for this article is retained by the author(s), with first publication rights granted to the journal.

This is an open-access article distributed under the terms and conditions of the Creative Commons Attribution license (http://creativecommons.org/licenses/by/4.0/). 